\title{
Synthesis and Spectroscopic Studies of Some New Molybdenum, Tungsten, and Ruthenium Carbonyl Derivatives of 2-Hydroxymethylpyridine
}

\author{
M. A. Taher, ${ }^{1}$ S. E. Jarelnabbi, ${ }^{2}$ B. E. Bayoumy, ${ }^{3}$ S. M. El-Medani, ${ }^{3}$ and R. M. Ramadan ${ }^{4}$ \\ ${ }^{1}$ Department of Chemistry, Faculty of Science, Al-Azhar University, Assiut Branch, Assiut, Egypt \\ ${ }^{2}$ Faculty of Agriculture, University of Khartoum, P.O. Box 32 Khartoum North, Sudan \\ ${ }^{3}$ Department of Chemistry, Community College, Baha University, Baha, P.O. Box 1598, Saudi Arabia \\ ${ }^{4}$ Department of Chemistry, Faculty of Science, Ain Shams University, Cairo, Egypt \\ Correspondence should be addressed to S. M. El-Medani, samirmedani@yahoo.com \\ Received 7 September 2009; Accepted 8 December 2009 \\ Academic Editor: Hakan Arslan
}

Copyright (๑) 2010 M. A. Taher et al. This is an open access article distributed under the Creative Commons Attribution License, which permits unrestricted use, distribution, and reproduction in any medium, provided the original work is properly cited.

Thermal reactions of 2-hydroxymethylpyridine (HMP) with $\left[\mathrm{M}(\mathrm{CO})_{6}\right]$ in air resulted in formation of the oxo-complexes $\left[\mathrm{M}_{2} \mathrm{O}_{6}(\mathrm{HMP})_{2}\right]$, where $\mathrm{M}=\mathrm{Mo}$, 1, or $\mathrm{W}$, 2. The tricarbonyl complex $\left[\mathrm{Ru}(\mathrm{CO})_{3}(\mathrm{HMP})\right]$, 3, was obtained from the reaction of $\left[\mathrm{Ru}_{3}(\mathrm{CO})_{12}\right]$ with $\mathrm{HMP}$. In presence of triphenyl phosphine $\left(\mathrm{PPh}_{3}\right)$, the reaction of $\mathrm{HMP}$ with $\mathrm{Ru} \mathrm{C}_{3}(\mathrm{CO})_{12}$ gave $\left[\mathrm{Ru}(\mathrm{CO})_{2}(\mathrm{HMP})\left(\mathrm{PPh}_{3}\right)\right]$, 4. All the complexes were characterized by elemental analysis, mass spectrometry, IR, and NMR spectroscopy. The thermal properties of the complexes were also investigated by thermogravimetry technique.

\section{Introduction}

Hydroxymethylpyridines are valuable intermediates and have promising application, for example, in the synthesis of pharmaceuticals and agrochemicals, such as mefloquine hydrochloride and pineprofen [1]. Carbonyl derivatives of transition metals, on the other hand, are useful intermediates in the synthesis of important coordination compounds [25] and have applications in catalysis of important reactions such as epoxidation, carbonylation, hydrogenation, and hydroformylation reactions [6-9]. For example, the complex $\left[\mathrm{Rh}(\mathrm{CO})_{2} \mathrm{Cl}(\mathrm{HMP})\right]$ was synthesized and characterized. It showed higher efficiency as catalyst for carbonylation of methanol to yield acetic acid and methyl acetate. It proved to be much better than the industrially used species $\left[\mathrm{Rh}(\mathrm{CO})_{2} \mathrm{I}_{2}\right]^{-}[10]$.

Molybdenum complexes also catalyze nitrogen fixation in plants by some microorganisms [11]. Many metal carbonyl derivatives are used in photochemical, photochromic, and thermochromic processes [12]. Pyridine derivatives have biological and pharmaceutical importance $[13,14]$. Oxidation-reduction of pyridine derivatives plays important roles in biological activity [15]. These derivatives are char- acterized by their antiviral, antifungal, antioxidant, antithyroid, and diuretic action [16]. Some pyridine complexes act as active catalysts for olefin polymerization [17].

Recently we have reported the reactions of $\left[\mathrm{Mo}(\mathrm{CO})_{6}\right]$ and $\left[\mathrm{Ru}_{3}(\mathrm{CO})_{12}\right]$ with 1-(2-pyridylazo)-2-naphthol (PAN) [18]. Several interesting structural features were indicated in those derivatives. Our interest in investigating the reactions of transition metal carbonyls with various pyridine derivatives has prompted us to investigate the reactions of 2-hydroxymethylpyridine, Scheme 1, with some metal carbonyls. The reactions were carried out in air with either HMP alone or in presence of triphenyl phosphine $\left(\mathrm{PPh}_{3}\right)$.

\section{Experimental}

2.1. Reagents. $\left[\mathrm{Mo}(\mathrm{CO})_{6}\right]$ and $\left[\mathrm{Ru}_{3}(\mathrm{CO})_{12}\right], \mathrm{HMP}$, and $\mathrm{PPh}_{3}$ were supplied by Fluka. All chemicals were of analytical reagent grade and were used without purification. All solvents were purified by distillation prior to their use.

2.2. Instrumentation. Infrared measurements ( $\mathrm{KBr}$ pellets) were carried out on a Unicam-Mattson 1000 FT-IR spectrometer. Electronic absorption spectra were measured on a 
TABLE 1: Elemental analysis and mass spectrometry data for the complexes.

\begin{tabular}{|c|c|c|c|c|c|c|}
\hline \multicolumn{2}{|c|}{ Complex } & \multirow{2}{*}{$\begin{array}{l}\text { C\% Found } \\
\text { (Calcd.) }\end{array}$} & \multirow{2}{*}{$\begin{array}{l}\text { H\% Found } \\
\text { (Calcd.) }\end{array}$} & \multirow{2}{*}{$\begin{array}{l}\text { N\% Found } \\
\text { (Calcd.) }\end{array}$} & \multicolumn{2}{|c|}{ Mass spectrometry } \\
\hline Molecular formula & Chemical formula & & & & $\begin{array}{c}\text { Molecular } \\
\text { weight }\end{array}$ & $m / z^{a}$ \\
\hline $\mathrm{Mo}_{2} \mathrm{O}_{6}(\mathrm{HMP})_{2}$ & {$\left[\mathrm{Mo}_{2}\left(\mathrm{C}_{12} \mathrm{H}_{14} \mathrm{O}_{8} \mathrm{~N}_{2}\right)\right]$} & $28.2(28.5)$ & $2.6(2.8)$ & $5.7(5.5)$ & 506.14 & $507\left[\mathrm{P}^{+}\right]$ \\
\hline $\mathrm{W}_{2} \mathrm{O}_{6}(\mathrm{HMP})_{2}$ & {$\left[\mathrm{~W}_{2} \mathrm{O}_{6}(\mathrm{HMP})_{2}\right]$} & $21.5(21.2)$ & $1.9(2.1)$ & $4.3(4.1)$ & 681.96 & $682\left[\mathrm{P}^{+}\right]$ \\
\hline $\mathrm{Ru}(\mathrm{CO})_{3}(\mathrm{HMP})$ & {$\left[\mathrm{Ru}\left(\mathrm{C}_{9} \mathrm{H}_{7} \mathrm{O}_{4} \mathrm{~N}\right)\right]$} & $36.5(36.8)$ & $2.2(2.4)$ & $4.6(4.8)$ & 294.23 & $239[\mathrm{P}-2 \mathrm{CO}]^{+}$ \\
\hline $\mathrm{Ru}(\mathrm{CO})_{2}(\mathrm{HMP})\left(\mathrm{PPh}_{3}\right)$ & {$\left[\mathrm{Ru}\left(\mathrm{C}_{26} \mathrm{H}_{22} \mathrm{O}_{3} \mathrm{NP}\right)\right]$} & $58.8(59.1)$ & $4.0(4.2)$ & $2.9(2.7)$ & 528.47 & $501[\mathrm{P}-\mathrm{CO}]^{+}$ \\
\hline
\end{tabular}

${ }^{a} \mathrm{~m} / z$ : mass over charge ratio in the mass spectrum.

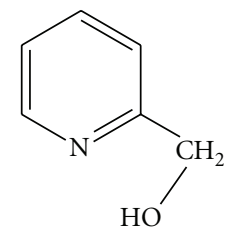

Scheme 1: 2-hydroxymethylpyridine (HMP).

Unicam UV2-300 spectrometer. Nuclear magnetic resonance measurements ( ${ }^{1} \mathrm{H}$ NMR) were performed on a SpectrospinBruker AC $200 \mathrm{MHz}$ spectrometer. Samples were dissolved in deuterated dimethylsulphoxide (DMSO) using tetramethylsilane (TMS) as internal reference. Magnetic measurements of the complexes in the solid state (Gouy method) were recorded on a Sherwood magnetic susceptibility balance. Elemental analyses for carbon, hydrogen, and nitrogen $(\mathrm{CHN})$ were performed on a Perkin-Elmer $2400 \mathrm{CHN}$ elemental analyzer. Mass spectrometry measurements of the solid complexes $(70 \mathrm{eV}, \mathrm{EI})$ were carried out on a Finnigan MAT SSQ 7000 spectrometer. Thermogravimetric (TG) analyses were carried out under nitrogen atmosphere with a heating rate of $10^{\circ} \mathrm{C} \min ^{-1}$ using a Shimadzu DT50 thermal analyzer. Table 1 gives the elemental analyses and mass spectrometry data of the complexes.

2.3. Synthesis of $\left[\mathrm{Mo}_{2} \mathrm{O}_{6}(\mathrm{HMP})_{2}\right]$ Complex (1). [Mo(CO) 6 $(0.10 \mathrm{~g}, 0.38 \mathrm{mmol})$ and HMP $(0.04 \mathrm{~g}, 0.38 \mathrm{mmol})$ were mixed in tetrahydrofuran (THF) $\left(\mathrm{ca} .30 \mathrm{~cm}^{3}\right)$ and then heated to reflux in air for 4 hours; a brown solution was formed. The reaction mixture was cooled and the solvent was evaporated under vacuum line. The solid residue was washed several times with boiling petroleum ether (60-80), recrystallized from hot THF to yield fine brown crystals and then dried under vacuum for several hours (yield 75\%).

2.4. Synthesis of $\left[\mathrm{W}_{2} \mathrm{O}_{6}(\mathrm{HMP})_{2}\right]$ Complex (2). Similar procedure was employed as used for the preparation of $\left[\mathrm{Mo}_{2} \mathrm{O}_{6}(\mathrm{HMP})_{2}\right]$ complex (reaction period: 10 hours; fine brown crystals; yield 80\%).

2.5. Synthesis of $\left[\mathrm{Ru}(\mathrm{CO})_{3}(\mathrm{HMP})\right]$ Complex (3). $\left[\mathrm{Ru}_{3}(\mathrm{CO})_{12}\right]$ $(0.032 \mathrm{~g}, 0.05 \mathrm{mmol})$, and HMP $(0.016 \mathrm{~g}, 0.15 \mathrm{mmol})$ were mixed in THF (ca. $30 \mathrm{~cm}^{3}$ ) and heated to reflux in air for 5 hours. After complete reaction, a brown solid was collected by filtration. The solid was washed several times with hot petroleum ether (60-80) and then recrystallized from hot ethanol giving fine brown crystals (yield 80\%).

2.6. Synthesis of $\left[\mathrm{Ru}(\mathrm{CO})_{2}(\mathrm{HMP})\left(\mathrm{PPh}_{3}\right)\right]$ Complex (4). A mixture of $\left[\mathrm{Ru}_{3}(\mathrm{CO})_{12}\right](0.032 \mathrm{~g}, 0.05 \mathrm{mmol}), \mathrm{HMP}(0.016 \mathrm{~g}$, $0.15 \mathrm{mmol}$ ) and $\mathrm{PPh}_{3}(0.04 \mathrm{~g}, 0.15 \mathrm{mmol})$ in THF (ca. $30 \mathrm{~cm}^{3}$ ) was heated to reflux in air for 4 hours. A reddishbrown solid was obtained, separated by filtration and then recrystallized from hot ethanol to give brownish crystals (yield 60\%).

\section{Results and Discussion}

3.1. IR and NMR Studies. Interaction of $\left[\mathrm{M}(\mathrm{CO})_{6}\right], \mathrm{M}$ $=$ Mo and $\mathrm{W}$, with 2-hydroxymethylpyridine (HMP) in THF in air gave the oxo complexes $\left[\mathrm{Mo}_{2} \mathrm{O}_{6}(\mathrm{HMP})_{2}\right], \mathbf{1}$, and $\left[\mathrm{W}_{2} \mathrm{O}_{6}(\mathrm{HMP})_{2}\right], 2$, respectively. The IR spectrum of HMP displayed characteristic stretching $(\nu)$ and bending $(\delta)$ bands due to its functional groups; $v(\mathrm{OH}), \delta(\mathrm{OH}), v(\mathrm{C}-\mathrm{O})$, $\nu(\mathrm{C}=\mathrm{N})$, and $\delta(\mathrm{Py})$, Table 2, [19-23]. The IR spectrum of the molybdenum complex, 1 , exhibited the ligand characteristic bands with the appropriate shifts due to complex formation, Table 2. The IR spectrum showed shifts in the $v(\mathrm{OH}), \delta(\mathrm{OH})$, and $v(\mathrm{C}-\mathrm{O})$ frequencies of the free ligand indicating the coordination of HMP to molybdenum through its oxygen atom of hydroxyl group. The magnetic studies showed that the oxo complex $\left[\mathrm{Mo}_{2} \mathrm{O}_{6}(\mathrm{HMP})_{2}\right], 1$, is diamagnetic. So, the ${ }^{1} \mathrm{H}$ NMR spectrum of $\mathbf{1}$ was performed and exhibited signals due to the ligand moieties, Table 3 . The presence of the $\mathrm{OH}$ group of ligand in $\mathbf{1}$ was also confirmed by ${ }^{1} \mathrm{H}$ NMR spectroscopy, Table 3. The higher shifts in the $v(\mathrm{OH})$ and $\delta(\mathrm{OH})$ on complexation may indicate the presence of intraand intermolecular hydrogen bonding [19]. Complex 1 also showed that the in-plane ring deformation bands, $\delta(\mathrm{Py})$, shifted to lower frequency. The shift of stretching frequency of the $\mathrm{C}=\mathrm{N}$ and $\delta(\mathrm{Py})$ of the pyridyl moiety indicated that pyridyl nitrogen is involved in coordination as well, Table 2 [20]. Furthermore, the IR spectrum of the complex displayed nonligand bands at $954 \mathrm{~cm}^{-1}$ and $880 \mathrm{~cm}^{-1}$ which were assigned owing to asymmetric and symmetric stretching frequencies of $\mathrm{Mo}=\mathrm{O}$ bonds in a cis $\mathrm{MoO}_{2}$ fragment of a dimeric structure having the core $\mathrm{Mo}_{2} \mathrm{O}_{6}[19,21]$. In addition, the IR spectrum of the complex exhibited two 
TABLE 2: Important IR data for HMP and its molybdenum, tungsten, and ruthenium complexes.

\begin{tabular}{|c|c|c|c|c|c|c|c|c|}
\hline \multirow{2}{*}{ Compound } & \multicolumn{8}{|c|}{ IR data $\left(\mathrm{cm}^{-1}\right)^{\mathrm{a}}$} \\
\hline & $v(\mathrm{OH})$ & $\nu(\mathrm{C}=\mathrm{O})$ & $\nu(\mathrm{C}=\mathrm{N})(\mathrm{Py})$ & $\nu(\mathrm{N}=\mathrm{N})$ & $\delta(\mathrm{OH})$ & $\nu(\mathrm{C}-\mathrm{O})$ & $\delta(\mathrm{Py})$ & $\gamma(\mathrm{C}-\mathrm{H})$ \\
\hline HMP & $3249(\mathrm{~s})$ & 一 & $1597(\mathrm{~s})$ & $1438(\mathrm{~s})$ & $1364(\mathrm{~m})$ & $1222(\mathrm{~m})$ & $633(\mathrm{~m})$ & - \\
\hline \multirow{4}{*}{$\mathrm{PPh}_{3}$} & - & - & - & - & - & - & - & $1430(\mathrm{~m})$ \\
\hline & - & - & - & - & - & - & - & $745(\mathrm{~s})$ \\
\hline & - & - & - & - & - & - & - & $694(\mathrm{~s})$ \\
\hline & - & - & - & - & - & - & - & $493(\mathrm{~s})$ \\
\hline$\left[\mathrm{Mo}_{2} \mathrm{O}_{6}(\mathrm{HMP})_{2}\right]^{\mathrm{b}}$ & $3445(\mathrm{~s})$ & - & $1609(\mathrm{~s})$ & $1478(\mathrm{~m})$ & $1401(\mathrm{~m})$ & $1288(\mathrm{~m})$ & $651(\mathrm{~m})$ & - \\
\hline$\left[\mathrm{W}_{2} \mathrm{O}_{6}(\mathrm{HMP})_{2}\right]^{\mathrm{c}}$ & $3424(\mathrm{~s})$ & 一 & $1613(\mathrm{~s})$ & $1441(\mathrm{~m})$ & $1400(\mathrm{~m})$ & $1286(\mathrm{~m})$ & $655(\mathrm{~m})$ & 一 \\
\hline$\left[\mathrm{Ru}(\mathrm{CO})_{3}(\mathrm{HMP})\right]^{\mathrm{d}}$ & $3423(\mathrm{~s})$ & $\begin{array}{c}2040(\mathrm{~m}) \\
1969(\mathrm{~s}) \\
1923(\mathrm{~s})\end{array}$ & $1650(\mathrm{~m})$ & $1458(\mathrm{~m})$ & $1432(\mathrm{~m})$ & $1282(\mathrm{~m})$ & $672(\mathrm{~m})$ & - \\
\hline \multirow{3}{*}[\mathrm{Ru}(\mathrm{CO})_{2}(\mathrm{HMP})(\mathrm{PPh}_{3})]{$^{\mathrm{e}}$} & \multirow{3}{*}{$3422(s)$} & $1972(\mathrm{~s})$ & & \multirow{3}{*}{$1433(\mathrm{~m})$} & \multirow{3}{*}{$1478(\mathrm{~m})$} & \multirow{3}{*}{$1186(\mathrm{~m})$} & \multirow{3}{*}{$695(\mathrm{~s})$} & $748(\mathrm{~m})$ \\
\hline & & $1896(\mathrm{~s})$ & $1651(\mathrm{~s})$ & & & & & $722(\mathrm{~m})$ \\
\hline & & - & & & & & & $517(\mathrm{~s})$ \\
\hline
\end{tabular}

${ }^{\mathrm{a}} \mathrm{s}$ : strong; m: medium.

${ }^{\mathrm{b}}$ The $v(\mathrm{Mo}-\mathrm{N}): 468 \mathrm{~cm}^{-1}(\mathrm{~m}) ; \nu(\mathrm{Mo}-\mathrm{O}): 540 \mathrm{~cm}^{-1}(\mathrm{~m}) ; v(\mathrm{Mo}=\mathrm{O}): 954 \mathrm{~cm}^{-1}(\mathrm{~s})$ and $880 \mathrm{~cm}^{-1}(\mathrm{~m}) ; \nu(\mathrm{Mo}-\mathrm{O}-\mathrm{Mo}): 800(\mathrm{~m})$ and $651 \mathrm{~cm}{ }^{-1}(\mathrm{~m})$.

${ }^{\mathrm{c}}$ The $\nu(\mathrm{W}-\mathrm{N}): 534 \mathrm{~cm}^{-1}(\mathrm{~m}) ; \nu(\mathrm{W}-\mathrm{O}): 565 \mathrm{~cm}^{-1}(\mathrm{~m}) ; \nu(\mathrm{W}=\mathrm{O}): 944 \mathrm{~cm}^{-1}$ (s) and $865 \mathrm{~cm}^{-1}(\mathrm{~s}) ; \nu(\mathrm{W}-\mathrm{O}-\mathrm{W}): 803(\mathrm{~s})$ and $655 \mathrm{~cm}^{-1}(\mathrm{~m})$.

${ }^{\mathrm{d}}$ The $v(\mathrm{Ru}-\mathrm{N}): 422 \mathrm{~cm}^{-1}(\mathrm{~m}) ; \nu(\mathrm{Ru}-\mathrm{O}): 558 \mathrm{~cm}^{-1}(\mathrm{~m})$.

e The $v(\mathrm{Ru}-\mathrm{N}): 459 \mathrm{~cm}^{-1}(\mathrm{~m}) ; v(\mathrm{Ru}-\mathrm{O}): 572 \mathrm{~cm}^{-1}(\mathrm{~m})$.

TABLe 3: ${ }^{1} \mathrm{H}$ NMR data of HMP and its molybdenum, tungsten, and ruthenium complexes.

\begin{tabular}{ll}
\hline Compound & ${ }^{1} \mathrm{H}$ NMR data $(\mathrm{ppm})$ \\
\hline $\mathrm{HMP}$ & $8.47(\mathrm{~s}, 1 \mathrm{H}, \mathrm{OH}), 7.79-7.73,7.50-7.47,7.22-7.20(\mathrm{~m}, 4 \mathrm{H}, \mathrm{py}), 5.44\left(\mathrm{~s}, 2 \mathrm{H}, \mathrm{CH}_{2}\right)$ \\
{$\left[\mathrm{Mo}_{2} \mathrm{O}_{6}(\mathrm{HMP})_{2}\right]$} & $9.99(\mathrm{~s}, 2 \mathrm{H}, 2 \mathrm{OH}), 8.41-8.39,8.05-7.89,7.60-7.36(\mathrm{~m}, 8 \mathrm{H}, 2 \mathrm{py}), 5.59\left(\mathrm{~s}, 4 \mathrm{H}, 2 \mathrm{CH}_{2}\right)$ \\
{$\left[\mathrm{W}_{2} \mathrm{O}_{6}(\mathrm{HMP})_{2}\right]$} & $9.99(\mathrm{~s}, 2 \mathrm{H}, 2 \mathrm{OH}), 8.71-8.44,8.10-7.68,7.67-6.11(\mathrm{~m}, 8 \mathrm{H}, 2 \mathrm{py}), 4.68\left(\mathrm{~s}, 4 \mathrm{H}, 2 \mathrm{CH}_{2}\right)$ \\
{$\left[\mathrm{Ru}(\mathrm{CO})_{3}(\mathrm{HMP})\right]$} & $8.75(\mathrm{~s}, 1 \mathrm{H}, \mathrm{OH}), 8.13-8.04,7.89-7.76,7.56-7.28(\mathrm{~m}, 4 \mathrm{H}, \mathrm{py}), 5.18\left(\mathrm{~s}, \mathrm{CH}_{2}\right)$ \\
{$\left[\mathrm{Ru}(\mathrm{CO})_{2}(\mathrm{HMP})\left(\mathrm{PPh}_{3}\right)\right]$} & $8.79(\mathrm{~s}, 1 \mathrm{H}, \mathrm{OH}), 7.78-7.22(\mathrm{~m}, 19 \mathrm{H}, \mathrm{py} \& \mathrm{Ph}), 4.53\left(\mathrm{~s}, 2 \mathrm{H}, \mathrm{CH}_{2}\right)$ \\
\hline
\end{tabular}

stretching vibrational bands at 800 and $651 \mathrm{~cm}^{-1}$ due to two $v$ (Mo-O-Mo) frequencies [19].

In the far IR spectrum of 1, nonligand bands at $540 \mathrm{~cm}^{-1}$ and $468 \mathrm{~cm}^{-1}$ due to $\mathrm{Mo}-\mathrm{O}$ and $\mathrm{Mo}-\mathrm{N}$ bonds provided further evidence for bonding of pyridyl nitrogen and hydroxyl oxygen to molybdenum [20, 24, 25]. Scheme 2 gives the proposed structure of the complex. According to the proposed structure, molybdenum may have +6 formal oxidation state with $d^{0}$ electronic configuration. Similarly, the reaction of $\left[\mathrm{W}(\mathrm{CO})_{6}\right]$ with HMP in THF in air resulted in the formation of the brown oxo complex $\left[\mathrm{W}_{2} \mathrm{O}_{6}(\mathrm{HMP})_{2}\right]$, 2. Spectroscopic studies of the complex revealed identical trend as observed for $\left[\mathrm{Mo}_{2} \mathrm{O}_{6}(\mathrm{HMP})_{2}\right]$ complex, Tables 2 and 3. Therefore, identical structure was proposed for both Mo and $\mathrm{W}$ complexes (Scheme 2).

Thermal reaction of a mixture of $\left[\mathrm{Ru}_{3}(\mathrm{CO})_{12}\right]$ and HMP produced a brown complex with a molecular formula of $\left[\mathrm{Ru}(\mathrm{CO})_{3}(\mathrm{HMP})\right], 3$. The IR spectrum of $\mathbf{3}$ displayed the ligand bands with the corresponding shifts due to complex formation, Table 2. In addition, three stretching bands (one medium and two strong) in the terminal metal carbonyl range were observed at 2040, 1969, and $1923 \mathrm{~cm}^{-1}$ due to three terminal $\mathrm{M}-\mathrm{C} \equiv \mathrm{O}$ bonds. The number and pattern of these bands suggested the presence of two axial and one equatorial $\mathrm{CO}$ groups in a trigonal bipyramidal structure as shown in Scheme $3[18,21]$. The IR spectrum of the ruthenium complex also displayed nonligand bonds at $422 \mathrm{~cm}^{-1}$ and $558 \mathrm{~cm}^{-1}$ due to $\mathrm{Ru}-\mathrm{N}$ and $\mathrm{Ru}-\mathrm{O}$ bonds, respectively. In addition, the IR spectrum showed a strong and broad band at $3423 \mathrm{~cm}^{-1}$ due to stretching frequency of the $\mathrm{OH}$ group, and a band at $1432 \mathrm{~cm}^{-1}$ due to bending $\mathrm{OH}$ frequency. Magnetic measurements of the complex indicated its diamagnetic characteristics. The ${ }^{1} \mathrm{H}$ NMR spectrum of 3 displayed a signal at $8.75 \mathrm{ppm}$ indicating the presence of the $\mathrm{OH}$ group. The signal showed lower field shift and indicated the coordination of HMP ligand to the ruthenium atom 
TABLE 4: Thermal analysis data for HMP and its molybdenum, tungsten, and ruthenium complexes.

\begin{tabular}{|c|c|c|c|c|c|}
\hline Complex & $\begin{array}{l}\text { Decomposition } \\
\text { step, K }\end{array}$ & \% Weight loss & Mol. wt. & Species eliminated & $\%$ Solid residue \\
\hline \multirow{3}{*}[\mathrm{Mo}_{2}(\mathrm{C}_{12}\mathrm{H}_{14}\mathrm{O}_{8}\mathrm{N}_{2})]{} & $490-620$ & 21.76 & 110.14 & $\mathrm{C}_{6} \mathrm{H}_{6}+\mathrm{O}_{2}$ & \multirow{3}{*}{$2 \mathrm{MoO} 44.26 \%$} \\
\hline & $620-760$ & 22.15 & 112.11 & $\mathrm{C}_{6} \mathrm{H}_{8}+\mathrm{O}_{2}$ & \\
\hline & $760-900$ & 11.86 & 60.03 & $2 \mathrm{NO}$ & \\
\hline \multirow{3}{*}[\mathrm{W}_{2}(\mathrm{C}_{12}\mathrm{H}_{14}\mathrm{O}_{8}\mathrm{N}_{2})]{} & $480-650$ & 12.48 & 85.11 & $\mathrm{C}_{4} \mathrm{H}_{5}+\mathrm{O}_{2}$ & \multirow{3}{*}{ 2WO58.61\% } \\
\hline & $650-800$ & 12.62 & 86.06 & $\mathrm{C}_{4} \mathrm{H}_{6}+\mathrm{O}_{2}$ & \\
\hline & $800-1000$ & 16.29 & 111.09 & $\mathrm{C}_{4} \mathrm{H}_{3}+2 \mathrm{NO}$ & \\
\hline \multirow{2}{*}[\mathrm{Ru}(\mathrm{C}_{9}\mathrm{H}_{7}\mathrm{O}_{4}\mathrm{N})]{} & $341-500$ & 19.04 & 56.02 & $2 \mathrm{CO}$ & \multirow{2}{*}{$\mathrm{RuO} 39.76 \%$} \\
\hline & $500-734$ & 41.20 & 121.22 & $\mathrm{C}_{7} \mathrm{H}_{7}+\mathrm{NO}$ & \\
\hline \multirow{3}{*}[\mathrm{Ru}(\mathrm{C}_{26}\mathrm{H}_{22}\mathrm{O}_{3}\mathrm{NP})]{} & $341-467$ & 10.60 & 56.02 & $2 \mathrm{CO}$ & \multirow{3}{*}{$\mathrm{RuO} 22.14 \%$} \\
\hline & $467-730$ & 27.67 & 146.23 & $\mathrm{C}_{11} \mathrm{H}_{14}$ & \\
\hline & $730-1200$ & 39.58 & 209.17 & $\mathrm{C}_{13} \mathrm{H}_{8} \mathrm{NP}$ & \\
\hline
\end{tabular}<smiles></smiles>

SCHeme 2: The proposed structure of $\left[\mathrm{M}_{2} \mathrm{O}_{6}(\mathrm{HMP})_{2}\right][\mathrm{M}=\mathrm{Mo}, 1$ or W, 2].

through the $\mathrm{OH}$ group. Accordingly, the complex may have zero formal oxidation state with $d^{8}$ electronic configuration as shown in Scheme 3.

Reaction of $\left[\mathrm{Ru}_{3}(\mathrm{CO})_{12}\right]$ with HMP in presence of $\mathrm{PPh}_{3}$ resulted in the formation of $\left[\mathrm{Ru}(\mathrm{CO})_{2}(\mathrm{HMP})\left(\mathrm{PPh}_{3}\right)\right], 4$. The mass spectrum of 4 gave a molecular ion peak at $\mathrm{m} / z=$ 501 corresponding to $[\mathrm{P}-\mathrm{CO}]^{+}$, Table 1 . The IR spectrum of the complex displayed the HMP and $\mathrm{PPh}_{3}$ characteristic bands with the appropriate shifts indicating the formation of a mixed ligands complex, Table 2. Also, the IR spectrum of 4 displayed two bands at 1972 and $1896 \mathrm{~cm}^{-1}$ in the terminal metal carbonyl region due to the presence of two terminal $\mathrm{CO}$ groups. In addition, the IR spectrum of the complex showed one stretching and one bending frequency due to the $\mathrm{OH}$ group at 3422 and $1478 \mathrm{~cm}^{-1}$, respectively. The shifts in $\mathrm{OH}$ bands with respect to that of ligand suggested that the $\mathrm{OH}$ group was involved in coordination. The magnetic studies showed that the complex is diamagnetic. The presence of the coordinated $\mathrm{OH}$ moiety was confirmed by ${ }^{1} \mathrm{H}$ NMR studies, Table 3 . The shifts observed for $\delta(\mathrm{Py})$ and $v(\mathrm{C}=\mathrm{N})$ in the IR spectrum of 4 on complexation indicated the binding of HMP to ruthenium via the pyridyl<smiles></smiles>

Scheme 3: The proposed structure of $\left[\mathrm{Ru}(\mathrm{CO})_{3}(\mathrm{HMP})\right], 3$.

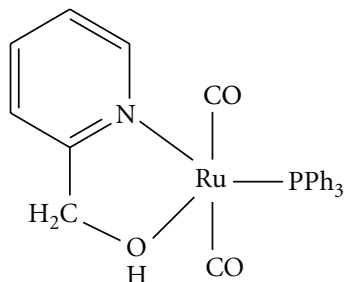

SCHEME 4: The proposed structure of $\left[\mathrm{Ru}(\mathrm{CO})_{2}(\mathrm{HMP})\left(\mathrm{PPh}_{3}\right)\right], 4$.

nitrogen, Table 2 . In the far IR spectrum of 4 , nonligand bands were observed at 459 and $572 \mathrm{~cm}^{-1}$ due to $(\mathrm{Ru}-\mathrm{N})$ and ( $\mathrm{Ru}-\mathrm{O})$ bonds [25]. According to the spectroscopic studies, the proposed structure given in Scheme 4 suggested that ruthenium metal may have zero formal oxidation state $\left(d^{8}\right.$ electronic configuration).

3.2. TG Analysis. In order to give more insight into the structure of the complexes, thermal studies on the solid complexes using TG and differential thermogravimetric (DTG) techniques were performed [26]. The TG and DTG plots of $\mathrm{Mo}_{2} \mathrm{O}_{6}(\mathrm{HMP})_{2}\left[\mathrm{Mo}_{2}\left(\mathrm{C}_{12} \mathrm{H}_{14} \mathrm{O}_{8} \mathrm{~N}_{2}\right) ; \mathrm{M}\right.$. wt. = 506.14] exhibited three decomposition steps. The first step occurred from $490-620 \mathrm{~K}$, with a net weight loss of $21.76 \%$, is probably due to elimination of $\left(\mathrm{C}_{6} \mathrm{H}_{6}+\mathrm{O}_{2}\right)$ moieties, Table 4 . The second step occurred from $620-760 \mathrm{~K}$ with a net weight loss of $22.15 \%$, is probably due to elimination of $\left(\mathrm{C}_{6} \mathrm{H}_{8}+\mathrm{O}_{2}\right)$. The third step occurred in the temperature range 760-900 K 
with a net weight loss of $11.86 \%$, consistent with elimination of $2 \mathrm{NO}$, to give finally $2 \mathrm{MoO}$, Table 4 .

The TG and DTG plots of $\mathrm{W}_{2} \mathrm{O}_{6}(\mathrm{HMP})_{2}$ $\left[\mathrm{W}_{2}\left(\mathrm{C}_{12} \mathrm{H}_{14} \mathrm{O}_{8} \mathrm{~N}_{2}\right)\right]$; M. wt. $\left.=681.96\right]$ exhibited also three decomposition steps in the temperature range 480-1000 K. The first, second, and third steps occurred in the temperature ranges (480-650), (650-800), and (800-1000) K with a net weight loss of $12.48 \%, 12.62 \%$ and $16.29 \%$ corresponding to the elimination of $\left(\mathrm{C}_{4} \mathrm{H}_{5}+\mathrm{O}_{2}\right),\left(\mathrm{C}_{4} \mathrm{H}_{6}+\mathrm{O}_{2}\right)$, and $\left(\mathrm{C}_{4} \mathrm{H}_{3}+\right.$ $2 \mathrm{NO})$, respectively, to give finally $2 \mathrm{WO}$ as residual, Table 4.

Thermal studies of the ruthenium complex, $\mathrm{Ru}(\mathrm{CO})_{3}$ (HMP), were carried out using thermogravimetry. The TG plot of $\mathrm{Ru}(\mathrm{CO})_{3}(\mathrm{HMP})\left[\mathrm{Ru}\left(\mathrm{C}_{9} \mathrm{H}_{7} \mathrm{O}_{4} \mathrm{~N}\right)\right.$; M. wt. = 294.23] showed two well-defined and non-overlapping steps in the $341-734 \mathrm{~K}$ range to give finally a solid residual of $\mathrm{RuO}$, Table 4.

A TG plot of $\mathrm{Ru}(\mathrm{CO})_{2}(\mathrm{HMP})\left(\mathrm{PPh}_{3}\right)\left[\mathrm{Ru}\left(\mathrm{C}_{26} \mathrm{H}_{22} \mathrm{O}_{3} \mathrm{NP}\right)\right.$; M. wt. $=528.47]$ showed three-step decomposition. The first at $341-467 \mathrm{~K}$, with a net weight loss of $10.60 \%$ corresponds to elimination of $2 \mathrm{CO}$ [26]. The second decomposition peak $(476-730 \mathrm{~K})$ showed a net weight loss of $27.67 \%$, Table 4 , and the third at $730-1200 \mathrm{~K}$, with a net weight loss of $39.58 \%$ to give finally a solid residual of RuO, Table 4 .

\section{Conclusion}

2-Hydroxymethylpyridine is an important substance in biological and pharmaceutical fields. Reactions of molybdenum, tungsten, and ruthenium carbonyls with HMP yielded the two oxo complexes $\left[\mathrm{Mo}_{2} \mathrm{O}_{6}(\mathrm{HMP})_{2}\right]$ and $\left[\mathrm{W}_{2} \mathrm{O}_{6}(\mathrm{HMP})_{2}\right]$ and the tricarbonyl complex $\left[\mathrm{Ru}(\mathrm{CO})_{3}(\mathrm{HMP})\right]$. In presence of $\mathrm{PPh}_{3}$ the reaction gave the dicarbonyl complex $\left[\mathrm{Ru}(\mathrm{CO})_{2}(\mathrm{HMP})\left(\mathrm{PPh}_{3}\right)\right]$.

\section{Acknowledgment}

The authors are gratefully acknowledged the generous support of SABEC Industrial Company and El-Baha University, Kingdom of Saudi Arabia.

\section{References}

[1] "Method for producing hydroxymethylpyridines," US Patent 6486327, Issued on November 2002.

[2] S. M. El-Medani, "Structural studies of some chromium, molybdenum and tungsten complexes of $N$-salicylidene-2hydroxyaniline," Journal of Coordination Chemistry, vol. 57, no. 2, pp. 115-122, 2004.

[3] S. M. El-Medani, "Reactions of chromium, molybdenum and tungsten carbonyls with a tetradentate schiff base," Journal of Coordination Chemistry, vol. 57, no. 6, pp. 497-507, 2004.

[4] M. M. H. Khalil, H. A. Mohamed, S. M. El-Medani, and R. M. Ramadan, "New group 6 metal carbonyl derivatives of 2-(2' pyridyl)benzimidazole: synthesis and spectroscopic studies," Spectrochimica Acta A, vol. 59, no. 6, pp. 1341-1347, 2003.

[5] S. M. El-Medani, M. M. Aboaly, H. H. Abdalla, and R. M. Ramadan, "Reactions of group 6 metal carbonyls with salicylaldehyde hydrazone," Spectroscopy Letters, vol. 37, no. 6, pp. 619-632, 2004.
[6] D. Chen and A. E. Martell, "Dioxygen affinities of synthetic cobalt Schiff base complexes," Inorganic Chemistry, vol. 26, no. 7, pp. 1026-1030, 1987.

[7] D. J. Darensbourg and J. D. Draper, "Binucleating coordination of $N, N^{\prime}$-ethylenebis(salicylideneamine) ( $\mathrm{H}_{2}$ salen) to low-valent group 6 carbonyl complexes," Inorganic Chemistry, vol. 37, no. 20, pp. 5383-5386, 1998.

[8] D. J. Darensbourg and M. W. Holtcamp, "Catalysts for the reactions of epoxides and carbon dioxide," Coordination Chemistry Reviews, vol. 153, pp. 155-174, 1996.

[9] J. Collman and L. S. Hegedus, Principles and Application of Organotransition Metal Chemistry, University Science Book, Sausalito, Claif, USA, 1980.

[10] B. J. Sarmah, B. J. Borah, B. Deb, and D. K. Dutta, "Dicarbonylrhodium(I) complexes of pyridine alcohol ligands and their catalytic carbonylation reaction," Journal of Molecular Catalysis A, vol. 289, no. 1-2, pp. 95-99, 2008.

[11] F. Barriere, "Modeling of the molybdenum center in the nitrogenase FeMo-cofactor," Coordination Chemistry Reviews, vol. 236, no. 1-2, pp. 71-89, 2003.

[12] J. Zhao, B. Zhao, J. Liu, W. Xu, and Z. Wang, "Spectroscopy study on the photochromism of Schiff bases $N, N^{\prime}$ bis(salicylidene)-1, 2-diaminoethane and $N, N^{\prime}$-bis(salicylidene)-1,6-hexanediamine," Spectrochimica Acta A, vol. 57, no. 1, pp. 149-154, 2001.

[13] M. N. Ackermann, W. G. Fairbrother, N. S. Amin, C. J. Deodene, C. M. Lamborg, and P. T. Martin, "Tetracarbonylmolybdenum complexes of 2-(phenylazo) pyridine ligands. Correlations of molybdenum-95 chemical shifts with electronic, infrared, and electrochemical properties," Journal of Organometallic Chemistry, vol. 523, no. 2, pp. 145-151, 1996.

[14] M. N. Ackermann, S. R. Kiihne, P. A. Saunders, and C. E. Barnes, "Synthesis and studies of cis- $\mathrm{Mo}(\mathrm{CO})_{2}\left(\mathrm{~L}-\mathrm{L}^{\prime}\right)_{2}$ and $\mathrm{Mo}\left(\mathrm{L}-\mathrm{L}^{\prime}\right)_{3}$ complexes of 2-(phenylazo)pyridines ( $\left.\mathrm{L}-\mathrm{L}^{\prime}\right)$ and the crystal structures of $\mathrm{Mo}(\mathrm{CO})_{2}$ (4-methyl-2-(phenylazo) pyridine $)_{2}$ and $\mathrm{Mo}(4 \text {-methyl-2-(phenylazo)pyridine) })_{3}$," Inorganica Chimica Acta, vol. 334, pp. 193-203, 2002.

[15] L. K. Ravindranath, S. R. Ramadas, and S. B. Rao, "Polarographic behaviour of arylazo pyrazoles," Electrochimica Acta, vol. 28, no. 5, pp. 601-603, 1983.

[16] B. E. Bayoumy and S. El Bahaie, "Synthesis of some new 1, 2, 3-selena and 1, 2, 3-thiodiazole derivatives," Acta Chimica Hungarica, vol. 3, p. 433, 1990.

[17] S. D. Ittel, L. K. Johnson, and M. Brookhart, "Late-metal catalysts for ethylene homo- and copolymerization," Chemical Reviews, vol. 100, no. 4, pp. 1169-1203, 2000.

[18] M. A. Taher, S. E. Jarelnabbi, A. G. M. Al-Sehemi, S. M. ElMedani, and R. M. Ramadan, "Synthesis and spectroscopic studies of some new metal carbonyl derivatives of 1-(2pyridylazo)-2-naphthol," Journal of Coordination Chemistry, vol. 62, no. 8, pp. 1293-1301, 2009.

[19] K. Nakamoto, Infrared and Raman Spectra of Inorganic and Coordination Compounds, John Wiley \& Sons, New York, NY, USA, 4th edition, 1986.

[20] R. M. Silverstein, G. C. Bassler, and T. C. Morrill, Spectrometric Identification of Organic Compounds, John Wiley \& Sons, New York, NY, USA, 4th edition, 1991.

[21] H. A. Mohamed, S. A. Ali, and R. M. Ramadan, "Spectroscopic and thermal studies of chromium(III), molybdenum(VI) and ruthenium $(0)$ complexes of maleic hydrazide," Spectrochimica Acta A, vol. 64, no. 4, pp. 913-917, 2006.

[22] M. Odabaolu, C. Albayrak, R. Zkanca, F. Z. Aykan, and P. Lonecke, "Some polyhydroxy azo-azomethine derivatives of salicylaldehyde: synthesis, characterization, spectroscopic, 
molecular structure and antimicrobial activity studies," Journal of Molecular Structure, vol. 840, no. 1-3, pp. 71-89, 2007.

[23] M. Panda, C. Das, C.-H. Hung, and S. Goswami, "Synthesis, structure, redox and spectra of green iridium complexes of tridentate azo-aromatic ligands," Journal of Chemical Sciences, vol. 119, no. 1, pp. 3-9, 2007.

[24] S. M. El-Medani, O. A. M. Ali, and R. M. Ramadan, "Photochemical reactions of group 6 metal carbonyls with $\mathrm{N}$-salicylidene-2-hydroxyaniline and bis-(salicylaldehyde)phenylenediimine," Journal of Molecular Structure, vol. 738, no. 1-3, pp. 171-177, 2005.

[25] A. A. Soliman and W. Linert, "Preparation, characterization and thermal study of new cerium(IV) complexes with the salicylidene-2-aminothiophenol schiff base," Synthesis and Reactivity in Inorganic and Metal-Organic Chemistry, vol. 29, no. 7, pp. 1133-1151, 1999.

[26] T. Hatakeyama and Z. Liu, Handbook of Thermal Analysis, John Wiley \& Sons, Chichester, UK, 1998. 


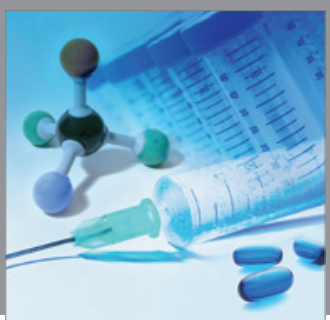

International Journal of

Medicinal Chemistry

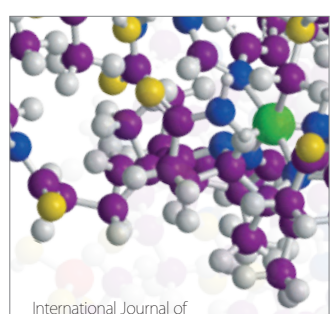

Carbohydrate Chemistry

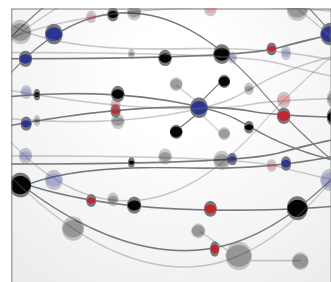

The Scientific World Journal
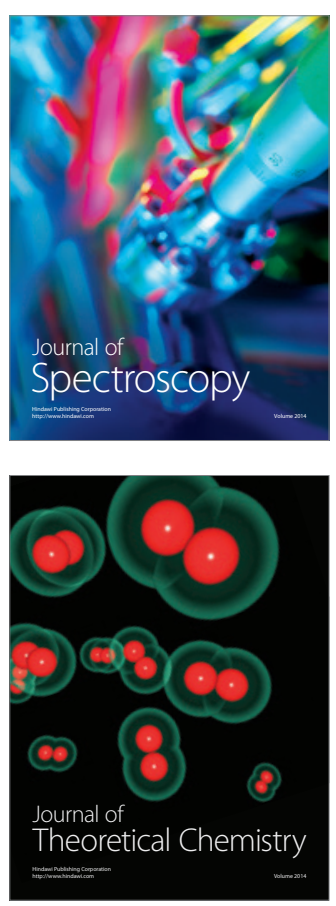
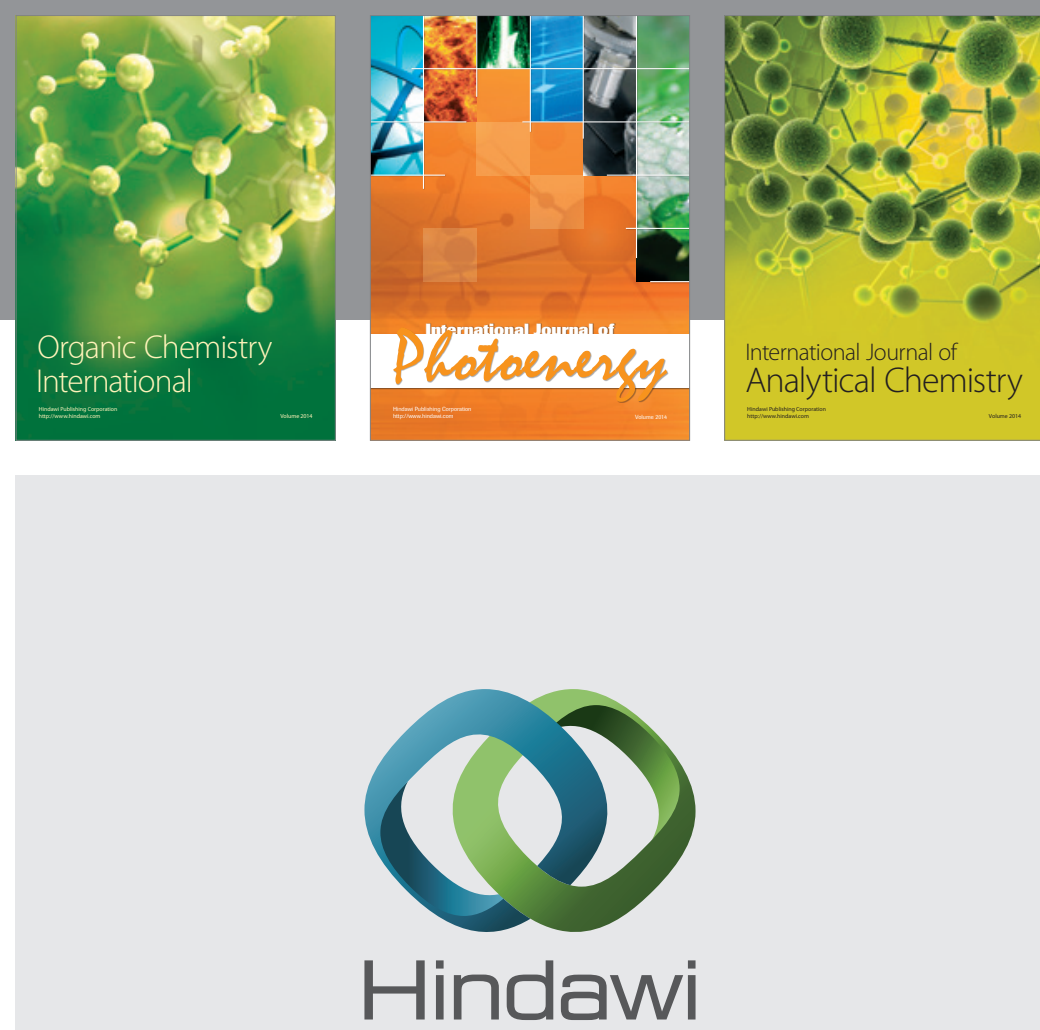

Submit your manuscripts at

http://www.hindawi.com
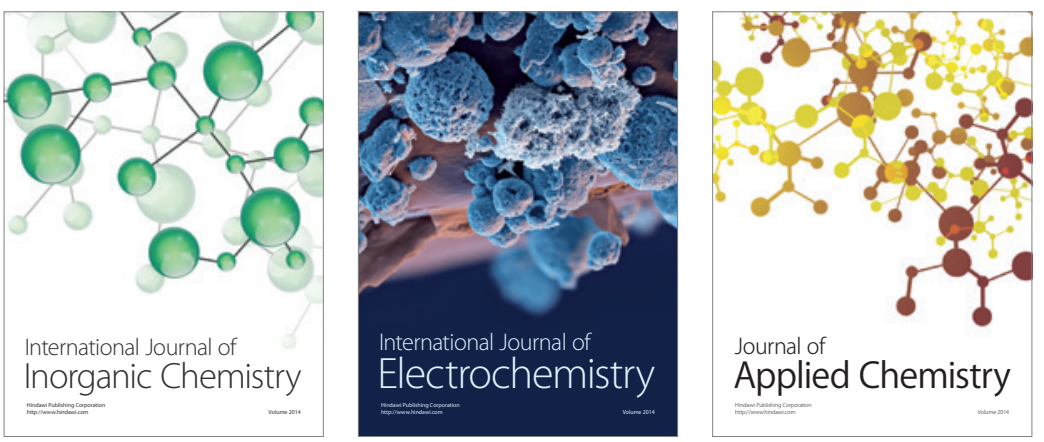

Journal of

Applied Chemistry
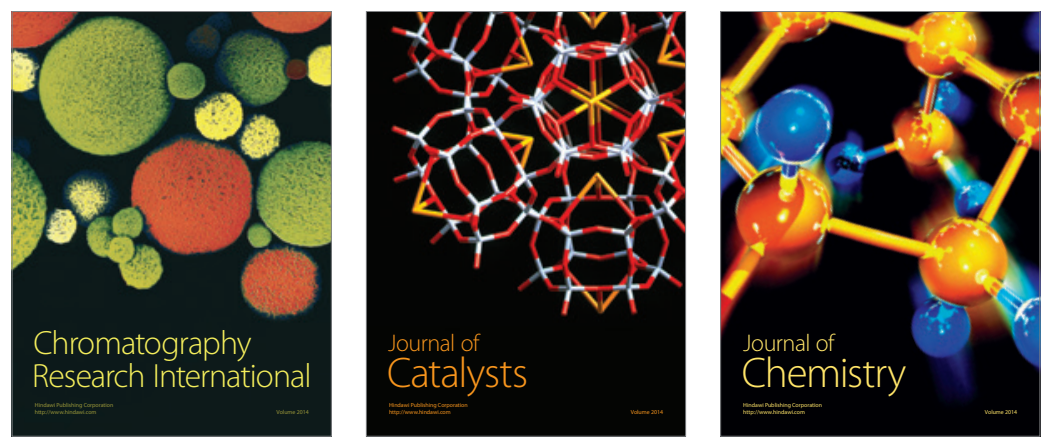
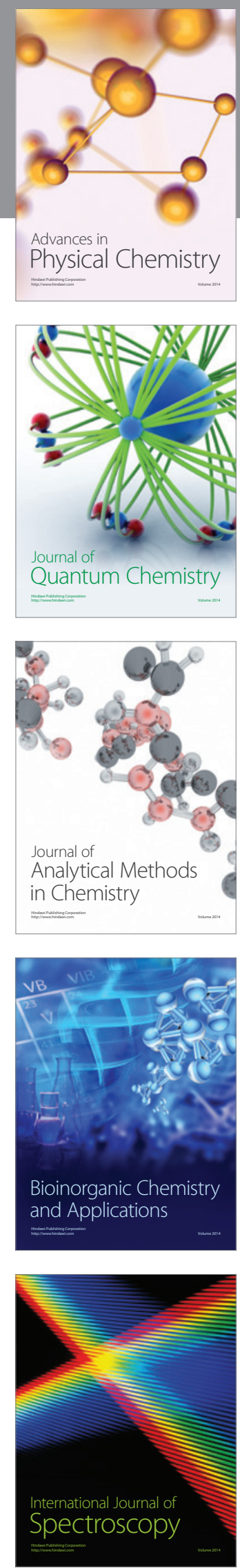